\title{
Perbandingan Nilai Kekuatan Tarik Komposit Menggunakan Metode Hand Lay Up Dan Metode Vari
}

\author{
Lega Putri Utami' ${ }^{1}$ Delovita Ginting ${ }^{2}$, Ahmad Kafrawi Nasution ${ }^{3}$ dan Budi Istana ${ }^{4}$ \\ 1,3,4Program Studi Teknik Mesin, Fakultas Teknik, Universitas Muhammadiyah Riau \\ ${ }^{2}$ Program Studi Fisika, Fakultas MIPA dan Kesehatan, Universitas Muhammadiyah Riau
}

Email : legaputri@umri.ac.id

\begin{abstract}
Abstrak
Beberapa metode pembuatan bahan/material komposit antara lain adalah Metode Vacuum Assited Resin Infunsion (VARI) dan Metode Hand Lay up. Tujuan penelitian ini adalah membandingkan nilai kekuatan tarik material komposit yang dibuat dengan menggunakan metode hand lay up dan VARI. Jenis serat yang dijadikan sebagai bahan komposit adalah serat pelepah sawit dan matrik yang digunakan polyester resin. Komposit yang diperkuat dengan pelepah sawit dicetak dengan menggunakan metode hand lay up dan VARI. Hasil penelitian menunjukkan nilai kekuatan tarik komposit dengan metode hand lay up sebesar 27,37 MPa dan kekuatan tarik komposit menggunakan metode VARI 28,40 MPa. Dari hasil penelitian di dapatkan perbedaan nilai kekuatan tarik dari kedua metode tersebut.
\end{abstract}

Kata kunci: Komposit, metode hand lay up, metode VARI, Kekuatan Tarik

\section{Abstract}

Some Types of the method of making composite materials are the Vacuum Assited Resin Infusion (VARI) Method and the Hand Lay Up Method. The purpose of this study was to compare the tensile strength of composite materials made using the hand lay up and VARI methods. The types of fibers used as composite materials are palm frond fibers and matrices used in polyester resin. Composites reinforced with palm fronds are printed using the hand lay up and VARI methods. The results showed the value of composite tensile strength with the hand lay up method of 27.37 MPa and composite tensile strength using the VARI method of $28.40 \mathrm{MPa}$. From the results of the study, the differences in the tensile strength values of the two methods were obtained.

Keywords: Composite, hand lay up method, VARI method, tensile strength

\section{PENDAHULUAN}

Penggunaan bahan komposit sebagai alternatif pengganti bahan logam dalam bidang rekayasa sudah semakin meluas, yang tidak hanya sebagai panel di bidang transportasi tetapi juga menambah pada bidang lainnya seperti property dan arsitektur. Hal ini dikarenakan oleh adanya keuntungan bahan komposit seperti konstruksi menjadi lebih ringan, tahan korosi dan kekuatannya dapat didesain sesuai dengan arah pembebanan. Saat ini ada beberapa metode pembuatan bahan/material komposit yang telah dikembangkan, salah satunya adalah Vacuum Assisted Resin Infusion (VARI). Metode Vacuum Assited Resin Infunsion (VARI) merupakan metode yang memanfaatkan perbedaan tekanan dari pompa vakum (Prayoga, 2013). Perbedaan tekanan ini akan menghisap resin dan masuk ke dalam cetakan lalu resin akan mengisi ruang antar serat yang sudah tersusun hingga memenuhi cetakan sehingga membentuk material komposit. Sistem kontrol tekanan vakum pada metode VARI menghasilkan produk komposit yang lebih baik daripada menggunakan metode hand lay up (Refiadi, dkk 2015)

Selain itu, proses VARI dapat mengurangi efek pengotoran yang banyak terjadi pada proses hand lay up dan menimbulkan kurang optimalnya sifat material komposit (Goren, 2008). Metode Vacuum Assisted Resin Infusion (VARI) sangat membantu dalam memperbaiki kualitas material. Penelitian ini bermaksud membandingkan kekuatan tarik komposit yang dibuat dengan menggunakan metode hand lay up dan VARI. 


\section{METODE PENELITIAN}

Penelitian ini dilakukan di Laboratorium Proses Produksi dan Laboratorium material Universitas Muhammadiyah Riau. Jenis Penelitan adalah penelitian eksperimen. Serat yang digunakan adalah serat pelepah sawit yang dibuat menggunakan dua metode pembuatan yaitu hand lay up dan VARI. Spesimen pengujian tarik menggunakan standar ASTM D 3039.
ALAT DAN BAHAN
1. Alat VARI
2. Cetakan kaca
3. Serat pelepah sawit
4. Polyester resin dan katalis MEKPO
5. Mirror graze

\section{HASIL DAN PEMBAHASAN}

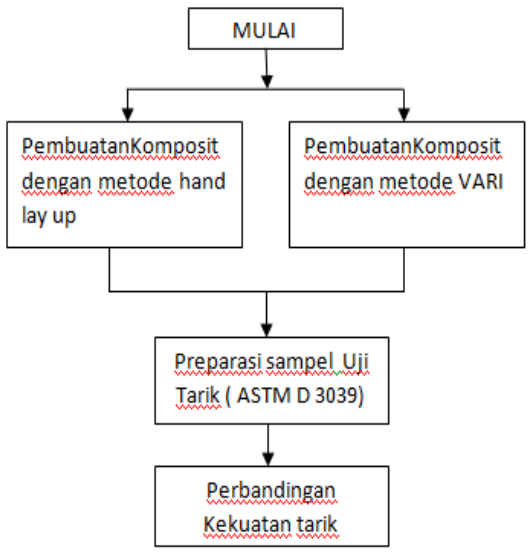

Dari penelitian di peroleh papan komposit dengan 2 metode pembuatan yaitu metode hand lay up dan menggunakan metode VARI. Papan komposit dibuat spesimen pengujian tarik menggunakan standar ASTM D3037. Dari pengujian tarik diperoleh data seperti gambar 2.

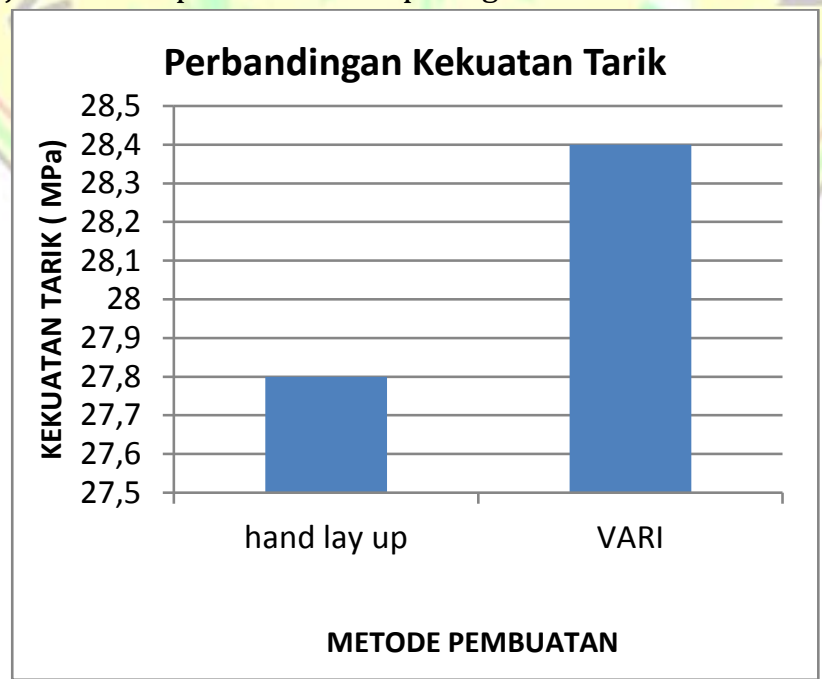

Gambar 2. Perbandingan kekuatan tarik menggunakan metode hand lay up dan VARI.

Dari Gambar 2 dapat dilihat kekuatan tarik spesimen komposit menggunakan metode hand lay up di peroleh nilai sebesar 27,8 MPa. Sebaliknya metode pembuatan komposit menggunakan VARI diperoleh 
nilai kekuatan tarik 28,4. Hal ini menunjukkan kekuatan tarik komposit dengan metode VARI memiliki nilai kekuatan tarik yang lebih tinggi dibandingkan metode hand lay up.

\section{KESIMPULAN}

Dari Penelitian yang telah dilakukan dapat diambil kesimpulan nilai kekuatan tarik komposit menggunakan metode VARI lebih tinggi dibandingkan dengan metode VARI

\section{UCAPAN TERIMAKASIH}

Terimakasih kepada RISTEKDIKTI yang telah mendanai penelitian ini. LP2M Universitas Muhammadiyah Riau yang sudah memfasilitasi dan membantu administrasi yang berhubungan dengan penelitian ini

\section{DAFTAR PUSTAKA}

Callister. 2010. Material Science And Engineering : An Introduction. New York: John Wiley \& Sons, Inc

Febrianto, S, 2011. Penggunaan Metode Vacuum Assisted Resin Infusion Pada Bahan Uji Komposit Sandwich Untuk Aplikasi Kapal Bersayap Wise-8 Depok Universitas Indonesia.

Prayoga, Aditya, 2013.Pembuatan Propeler Blade Komposit Ijuk - Resin Untuk Turbin Mikro Hidro Kapasitas 550W dengan Teknik Vacuum Asisted Resin Infusion. Skripsi, Teknik Mesin Universitas Pasundan.

Refiadi Gunawan, 2005.Pembuatan Material Komposit dengan Metode Vacuum Asisted Resin Infusion. Berita Teknologi dan Barang Teknik No 19/2005. 